\title{
Assessment of Wild Brinjal (Solanum gilo) Genotypes of North-Eastern Region
}

\author{
Lalhming Sanga $^{1 *}$, A.K. Pandey ${ }^{1}$, S.D. Warade ${ }^{1}$, B.N. Hazarika ${ }^{2}$ and Siddhartha Singh ${ }^{3}$ \\ ${ }^{1}$ Department of Vegetable Science, ${ }^{2}$ Department of Fruit Science, ${ }^{3}$ Department of Basic \\ Sciences and Humanities, College of Horticulture and Forestry, CAU, \\ Pasighat, Arunachal Pradesh, Pin-791102, India \\ *Corresponding author
}

\section{A B S T R A C T}

\begin{tabular}{|c|}
\hline Keywords \\
\hline $\begin{array}{l}\text { Wild brinjal, } \\
\text { Solanum gilo, } \\
\text { Quality, } \\
\text { Biochemical. }\end{array}$ \\
\hline Article Info \\
\hline $\begin{array}{l}\text { Accepted: } \\
\text { 14 September } 2017 \\
\text { Available Online: } \\
10 \text { October } 2017\end{array}$ \\
\hline
\end{tabular}

Wild brinjal (Solanum gilo) genotypes were collected from different parts of North eastern region of India and evaluated to study the variability in vegetative, fruit yield and quality characters at research farm of department of Vegetable Science, College of Horticulture and Forestry, Central Agricultural University, Pasighat, Arunachal Pradesh, India during 2015 to 2016. The experiment was laid out in Randomized Block Design (RBD) with 15 genotypes and 3 replications. The results showed that the genotypes exhibited marked variation in growth, fruiting characteristics and biochemical components. Among all the genotypes, fruit weight $(27.86 \mathrm{~g})$, total carbohydrate $(375.78 \mathrm{mg} / 100 \mathrm{~g})$, ascorbic acid content $(16.73 \mathrm{mg} / 100 \mathrm{~g})$, total alkaloid $(4.68 \mathrm{mg} / 100 \mathrm{~g})$ was found highest in CHFG-4. CHFG-5 had highest number of fruits per plant (93.66), fruit yield per plant (1.97 kg), total phenol $(15.27 \mathrm{mg} / 100 \mathrm{~g})$. Hence, for fruit yield and quality characteristics, the genotypes CHFG-4 and CHFG-5 were best suited for cultivation in different parts of NEH region.

\section{Introduction}

Solanum gilo is commonly known as bitter brinjal. It is an important indigenous leaf and fruit vegetable in tropical Africa; cultivated and consumed largely in Africa (Sunseri et al., 2010). It is important for production in marginal areas and for the genetic improvement of $S$. melongena (Toppino et al., 2008). It is a self-pollinating crop, although some outcrossing of upto $30 \%$ is possible. Wide variations exists within and between the species including variation in characters like diameter of corolla, petiole length, leaf blade width, plant branching, fruit shape and color (Chinedu et al., 2011). The fruits are round, the top and bottom are flattened out and have grooved portions with a length of 5-6 cm and a width of $6-7 \mathrm{~cm}$. It has very tiny seeds and its stalk is curved or erect (Knapp, 2011). This species of garden egg have bitter tastes and is cultivated in the same way with other species. The fruit turn red or orange in color when ripened.

Their uses in indigenous medicine range from weight reduction to treatment of several ailments including asthma, allergic rhinitis, nasal catarrh, skin infections, rheumatic disease and swollen joint pains, gastrooesophageal reflux disease, constipation, dyspepsia (Bello et al., 2005). Its fruits 
possess analgesic, anti-inflammatory, antiasthmatic, anti-glaucoma, hypoglycaemic, hypolipidemic properties (Odetola et al., 2004). These pharmacological properties have been attributed to the presence of certain chemical substances in the plants, such as fiber, ascorbic acid, phenols, anthocyanin, glycoalkaloids and $\alpha$-chaconine (SanchezMata et al., 2010).

Although bitter brinjal is cultivated in all the state of North eastern region of India but there is no improved variety that can be recommended to the farmers for its commercial cultivation in the region. Therefore, studies were conducted to find out variation in physicochemical characters of 15 genotypes of wild brinjal and to achieve superior cultivar with satisfactory yield along with good fruit quality under the condition of North eastern region.

\section{Materials and Methods}

\section{Plant materials}

Fifteen wild brinjal (Solanum gilo) genotypes were collected from different part of the North eastern region of India and cultivated at research farm of department of Vegetable Science, College of Horticulture and Forestry, Central Agricultural University, Pasighat, Arunachal Pradesh, India during 2015 to 2016.

The list of genotypes along with their sources and morphological traits is given in (Table 1).

The experiment was laid out in Randomized Block Design (RBD) with 15 genotypes and 3 replications. The field was ploughed and made to a fine tilth. Five weeks old seedlings were transplanted in raised beds in rows spaced at $45 \mathrm{~cm}$ with plant-to-plant spacing of $45 \mathrm{~cm}$.

\section{Quantitative characters}

Data were recorded on five randomly selected plants of each genotype from each replication and the average was worked out in each replication for different traits. Plant height was recorded when in $50 \%$ of the plants the first fruit has attained mature stage and it was measured from the base to the highest tip of the plant, days to first flowering was recorded when the number of days required from transplanting until $50 \%$ of plants has at least one open flower, days to first fruit set was studied when the number of days from transplanting until $50 \%$ of plants has at least fruit set, days to first harvesting was recorded when the number of days to first harvest was counted from date of transplanting of seedling to the date of first harvesting, average fruit girth of 5 mature fruits were measured by using a digital Vernier caliper at the middle of the fruit and expressed in $\mathrm{cm}$, average fruit length of 5 mature fruits of the second harvest was measured from stalk to the bottom end by using a digital Vernier caliper and expressed in $\mathrm{cm}$, the total number of fruits harvested from all pickings of individual plant weighed and the average fruit weight worked out by dividing total weight of fruits from all the pickings with total number of fruits from all pickings and expressed in gram $(\mathrm{g})$, total number of fruits harvested from all pickings of individual plant was counted and summed up to get total number of fruits per plant, the fruit from each picking was recorded from 5 labeled plants of each genotype and total fruit per plant was worked out by adding the yield of all the harvest.

\section{Biochemical components}

The biochemical component of fruits from each genotypes of each replication was worked out and observations were recorded. Total carbohydrate content was determined by the method described by Hedge and Hofreiter 
(1962). A standard graph was drawn by plotting concentration of the standard on the $\mathrm{X}$-axis versus absorbance on the $\mathrm{Y}$-axis. From the graph the amount of carbohydrate present in the sample was calculated. The total phenol content was determined by the method described by Malick and Singh (1980). The concentration of phenols in the test sample was calculated from the standard curve and expressed as $\mathrm{mg}$ phenols/100 $\mathrm{g}$ material. The ascorbic acid content was determined by the method described by Jagota and Dani (1982). The concentration of ascorbic acid in the sample was calculated from the slope of the ascorbic acid standard curve. Total alkaloid content was determined by the method described by Vijay and Rajendra (2014). The absorbance for test and standard solutions were determined against the reagent blank at $470 \mathrm{~nm}$ with an UV/Visible spectrophotometer. The total alkaloid content was expressed as mg /100g of extract. Steroid content was determined by the method described by Jaroslav and Maurice (1979). The absorbance for sample was determined against the reagent blank at $470 \mathrm{~nm}$ with an UV/Visible spectrophotometer. Steroid content was expressed as $\mu \mathrm{g}$. Flavonoid content was determined by the method described by Vijay and Rajendra (2014). The absorbance for test and standard solutions were determined against the reagent blank at $510 \mathrm{~nm}$ with an UV/Visible spectrophotometer. The total flavonoid content was expressed as $\mathrm{mg} / 100 \mathrm{~g}$ of extract. Protein content was estimated by the method described by Lowry et al., (1951). Reading was taken at $660 \mathrm{~nm}$ and the amount of protein in the sample was calculated from a standard curve and expressed as mg protein/100 g sample.

\section{Statistical analysis}

Statistical analysis of the data was carried out by the method of analysis of variance as outlined by (Gomez and Gomez, 1983).

\section{Result and Discussion}

\section{Quantitative characters}

The data obtained on quantitative characters of wild brinjal (Solanum gilo) revealed significant differences among different genotypes during both the years of study Table 2(a) and 2(b). The pooled data of consecutive two years has shown that maximum plant height was recorded in CHFG-12 (63.18) which was statistically at par with CHFG-14 (61.75), CHFG-10 (61.74), CHFG-9 (61.50) and CHFG-15 (57.85). Minimum plant height was recorded in CHFG-5 (45.91). The present findings are in agreement with Hassan et al., (2015) and Kumar and Arumugam (2013) in brinjal. Minimum numbers of days to first flowering (50\%) was reported in CHFG-2 (58.0) which was statistically at par with CHFG-11 (59.66) while maximum days was recorded in CHFG13 (74.16). Similar results were obtained in brinjal by Yadav et al., (2014). The pooled data has shown that minimum number of days to first fruit set was observed in CHFG-2 (69.84) which was statistically at par with CHFG-11 (71.66) while maximum number of days to first fruit set was observed in CHFG13 (85.50). The genotypes having lower days to harvesting can be exploited for earliness in yield. Minimum number of days to first harvesting was recorded in CHFG-2 (82.84) which was statistically at par with CHFG-11 (84.66) while maximum number of days was recorded in CHFG-13 (98.50). Similar results of a significant varietal difference in brinjal were obtained by Singh and Kumar (2005). Maximum fruit girth was observed in CHFG1 (4.53) which was statistically at par with CHFG-3 (4.48), CHFG-9 (4.44), CHFG-4 (4.41), CHFG-12 (4.37), CHFG-11 (4.31), CHFG-2 (4.30) and CHFG-7 (4.25) while CHFG-6 (2.62) had minimum girth. Maximum fruit length was recorded in CHFG-15 (2.97) while it was minimum in CHFG-8 (2.38). 
Table.1 List of wild brinjal (Solanum gilo) genotypes with their source and morphological traits

\begin{tabular}{|c|c|c|c|c|c|c|}
\hline Genotype & Source & Leaf blade width & Leaf blade lobing & Fruit colour & Fruit shape & Fruiting habit \\
\hline CHFG-1 & A landrace of Lawngtlai, Mizoram & Wide & Intermediate & Light green & About $1 / 2$ way from base to tip & Cluster \\
\hline CHFG-2 & A land race of Khawzawl, Mizoram & Intermediate & Strong & White & About $1 / 2$ way from base to tip & Cluster and solitary \\
\hline CHFG-3 & A landrace of Sialsuk, Mizoram & Intermediate & Strong & Purple & About $1 / 2$ way from base to tip & Cluster and solitary \\
\hline CHFG-4 & A landrace of Keifang, Mizoram & Wide & Intermediate & Dark green & About $1 / 2$ way from base to tip & Cluster \\
\hline CHFG-5 & A landrace of Balek, Arunachal Pradesh & Intermediate & Strong & Green & About $3 / 4$ way from base to tip & Cluster and solitary \\
\hline CHFG-6 & A landrace of Yang yang, East Sikkim & Wide & Intermediate & Light green & About $1 / 2$ way from base to tip & Cluster and solitary \\
\hline CHFG-7 & A landrace of Mizoram & Wide & Intermediate & Light green & About $1 / 2$ way from base to tip & Cluster \\
\hline CHFG-8 & A landrace of Ledum, Arunachal Pradesh & Intermediate & Strong & Green & About $3 / 4$ way from base to tip & Cluster and solitary \\
\hline CHFG-10 & A landrace of Churachandpur, Manipur & Intermediate & Intermediate & Purple & About $3 / 4$ way from base to tip & Cluster and solitary \\
\hline CHFG-11 & A landrace of Mizoram & Intermediate & Strong & White & About $1 / 2$ way from base to tip & Cluster \\
\hline CHFG-12 & A landrace of Mizoram & Wide & Intermediate & Blackish green & About $1 / 2$ way from base to tip & Cluster and solitary \\
\hline CHFG-13 & A landrace of Aalo, West Siang, Arunachal Pradesh & Wide & Intermediate & Light green & About $1 / 2$ way from base to tip & Cluster \\
\hline CHFG-14 & A landrace of Shillong, Meghalaya & Intermediate & Intermediate & Green & About $3 / 4$ way from base to tip & Cluster \\
\hline CHFG-15 & A landrace of East Lungdar, Mizoram & Intermediate & Intermediate & Green & About $1 / 2$ way from base to tip & Cluster and solitary \\
\hline
\end{tabular}

Table.2 (a) Vegetative characteristics of different wild brinjal (Solanum gilo) genotypes

\begin{tabular}{|c|c|c|c|c|c|c|c|c|c|c|c|c|c|}
\hline \multirow{2}{*}{ S.N. } & \multirow{2}{*}{ Genotype } & \multicolumn{3}{|c|}{ Plant height (cm) } & \multicolumn{3}{|c|}{ Days to $1^{\text {stflowering }(50 \%)}$} & \multicolumn{3}{|c|}{ Days to $1^{\text {st }}$ fruit set $(50 \%)$} & \multicolumn{3}{|c|}{ Days to1 ${ }^{\text {st }}$ harvesting } \\
\hline & & $15-16$ & 16-17 & pool & $15-16$ & $16-17$ & pool & $15-16$ & 16-17 & \begin{tabular}{|l|} 
pool \\
\end{tabular} & $15-16$ & \begin{tabular}{|l|}
$16-17$ \\
\end{tabular} & pool \\
\hline 1. & CHFG-1 & 49.91 & 51.16 & 50.54 & 68.34 & 67.00 & 67.66 & 79.34 & 77.00 & 78.16 & 89.00 & 88.67 & 88.84 \\
\hline 2. & CHFG-2 & 55.67 & 57.26 & 56.46 & 58.34 & 57.67 & 58.00 & 70.67 & 69.00 & 69.84 & 83.67 & 82.00 & 82.84 \\
\hline 3. & CHFG-3 & 50.5 & 52.25 & \begin{tabular}{|l|l|l}
51.37 \\
\end{tabular} & 62.67 & 63.34 & 63.00 & 74.34 & 73.67 & 74.00 & \begin{tabular}{|l|}
87.67 \\
\end{tabular} & 87.00 & 87.34 \\
\hline 4. & CHFG-4 & 53.83 & 55.30 & 54.56 & 67.67 & 66.00 & 66.84 & 78.00 & 77.67 & 77.84 & 90.67 & 90.34 & 90.50 \\
\hline 5. & \begin{tabular}{|l|} 
CHFG-5 \\
\end{tabular} & 45.34 & 46.50 & 45.91 & 63.67 & 62.34 & 63.00 & 75.34 & 73.67 & 74.50 & 86.34 & 86.00 & 86.16 \\
\hline 6. & \begin{tabular}{|l|} 
CHFG-6 \\
\end{tabular} & 49.00 & 50.50 & 49.75 & 73.34 & 72.00 & 72.66 & 84.00 & 83.67 & 83.84 & 97.34 & 96.00 & 96.66 \\
\hline 7. & CHFG-7 & 52.24 & 53.41 & 52.82 & 69.34 & 68.66 & 69.00 & 80.67 & 79.67 & 80.16 & 92.67 & 92.34 & 92.50 \\
\hline 8. & CHFG-8 & 51.83 & 53.06 & 52.45 & 67.34 & 66.00 & 66.66 & 78.34 & 77.34 & 77.84 & 91.34 & 91.00 & 91.16 \\
\hline 9. & \begin{tabular}{|l|} 
CHFG-9 \\
\end{tabular} & 60.75 & 62.26 & 61.50 & 67.66 & 67.00 & 67.34 & 78.67 & 77.00 & 77.84 & 92.34 & 91.67 & 92.00 \\
\hline 10. & \begin{tabular}{|l|} 
CHFG-10 \\
\end{tabular} & 61.30 & 61.96 & 61.74 & 65.67 & 65.34 & 65.50 & 76.67 & 76.34 & 76.50 & \begin{tabular}{|l|l|}
89.67 \\
\end{tabular} & 89.34 & 89.50 \\
\hline 11. & CHFG-11 & 46.50 & 47.94 & 47.21 & 60.34 & 59.00 & 59.66 & 72.00 & 71.34 & 71.66 & 85.00 & 84.34 & 84.66 \\
\hline 12. & CHFG-12 & 62.16 & 64.20 & 63.18 & 69.00 & 68.34 & 68.84 & 80.67 & 79.67 & 80.16 & 94.34 & 93.00 & 93.66 \\
\hline 13. & \begin{tabular}{|l|} 
CHFG-13 \\
\end{tabular} & 48.13 & 48.78 & 48.45 & 75.34 & 73.00 & 74.16 & 86.34 & 84.67 & 85.50 & 99.34 & 97.67 & 98.50 \\
\hline 14. & CHFG-14 & 61.50 & 62.00 & 61.75 & 72.67 & 71.00 & 71.84 & 83.00 & 82.34 & 82.66 & 96.67 & 95.34 & 96.00 \\
\hline 15. & CHFG-15 & 57.00 & 58.70 & 57.85 & 64.67 & 64.00 & 64.34 & 75.67 & 75.34 & 75.50 & 91.67 & 89.67 & 91.34 \\
\hline \multicolumn{2}{|r|}{ Mean } & 54.22 & 55.02 & 54.37 & 66.97 & 66.04 & 66.56 & 78.23 & 77.24 & 77.74 & 91.17 & 90.38 & 90.77 \\
\hline \multicolumn{2}{|r|}{$\mathrm{CV} \%$} & 6.08 & 5.80 & 5.47 & 4.01 & 3.93 & 3.67 & 3.35 & 3.34 & 3.09 & 2.89 & 2.59 & 2.49 \\
\hline \multicolumn{2}{|r|}{ SEm \pm} & 1.89 & 1.83 & 1.21 & 1.54 & 1.50 & 0.99 & 1.50 & 1.49 & 0.98 & 1.52 & 1.35 & 0.92 \\
\hline \multicolumn{2}{|c|}{ CD or LSD (5\%) } & 5.50 & 5.30 & 3.42 & 4.48 & 4.36 & 2.81 & 4.37 & 4.33 & 2.76 & 4.40 & 3.92 & 2.61 \\
\hline
\end{tabular}


Table.2 (b) Fruit yield and quality characteristics of different wild brinjal (Solanum gilo) genotypes

\begin{tabular}{|c|c|c|c|c|c|c|c|c|c|c|c|c|c|c|c|c|}
\hline \multirow{2}{*}{ S.N. } & \multirow{2}{*}{ Genotype } & \multicolumn{3}{|c|}{ Fruit girth $(\mathbf{c m})$} & \multicolumn{3}{|c|}{ Fruit length $(\mathrm{cm})$} & \multicolumn{3}{|c|}{ Fruit weight (g) } & \multicolumn{3}{|c|}{ Number of fruits per plant } & \multicolumn{3}{|c|}{ Fruit yield per plant (kg) } \\
\hline & & $15-16$ & 16-17 & pool & $15-16$ & 16-17 & pool & $15-16$ & 16-17 & pool & $15-16$ & 16-17 & pool & $15-16$ & 16-17 & pool \\
\hline 1. & \begin{tabular}{|l|} 
CHFG-1 \\
\end{tabular} & 4.47 & 4.58 & 4.53 & 2.82 & 2.86 & 2.84 & 26.84 & 27.90 & 27.37 & 69.00 & 70.67 & 69.84 & 1.89 & \begin{tabular}{|l|}
1.92 \\
\end{tabular} & 1.90 \\
\hline 2. & CHFG-2 & 4.27 & 4.32 & 4.30 & 2.72 & 2.75 & 2.74 & 25.54 & 25.06 & 24.80 & 74.67 & 75.34 & 75.0 & 1.83 & 1.87 & 1.85 \\
\hline 3. & CHFG-3 & 4.42 & \begin{tabular}{|l|l|}
4.54 \\
\end{tabular} & 4.48 & 2.79 & 2.82 & 2.81 & 25.87 & 26.91 & 26.39 & 68.67 & 70.00 & 69.34 & 1.61 & 1.64 & 1.64 \\
\hline 4. & CHFG-4 & 4.35 & 4.47 & 4.41 & 2.80 & 2.85 & 2.83 & 27.11 & 27.54 & 27.32 & 71.34 & 72.00 & 71.66 & 1.91 & 1.97 & 1.95 \\
\hline 5. & CHFG-5 & 2.91 & 2.99 & 2.95 & 2.40 & 2.43 & 2.42 & 20.64 & 21.54 & 21.08 & 93.00 & 94.34 & 93.66 & 1.93 & 2.03 & 1.97 \\
\hline 6. & CHFG-6 & 2.58 & 2.65 & 2.62 & 2.38 & 2.39 & 2.39 & 16.57 & 16.84 & 16.70 & 65.34 & 66.00 & 65.67 & 0.75 & 0.86 & 0.81 \\
\hline 7. & CHFG-7 & 4.24 & 4.25 & 4.25 & 2.83 & 2.88 & 2.85 & 26.16 & 27.06 & 26.61 & 69.67 & 70.67 & 70.16 & 1.71 & 1.80 & 1.75 \\
\hline 8. & CHFG-8 & 2.79 & 2.84 & 2.82 & 2.35 & 2.41 & 2.38 & 20.08 & 21.42 & 20.75 & 89.67 & 91.00 & 90.34 & 1.78 & 1.91 & \begin{tabular}{|l|l|}
1.82 \\
\end{tabular} \\
\hline 9. & CHFG-9 & 4.39 & 4.50 & 4.44 & 2.78 & 2.81 & 2.79 & 26.06 & 27.30 & 26.68 & 70.00 & 70.34 & 70.16 & 1.72 & 1.81 & 1.76 \\
\hline 10. & CHFG-10 & 2.83 & 2.86 & 2.85 & 2.46 & 2.50 & 2.48 & 17.25 & 18.32 & 17.79 & 73.00 & 73.67 & 73.34 & 1.25 & \begin{tabular}{|l|}
1.34 \\
\end{tabular} & 1.30 \\
\hline 11. & CHFG-11 & 4.29 & 4.34 & 4.31 & 2.61 & 2.69 & 2.65 & 24.00 & 25.26 & 24.63 & 76.34 & 77.00 & 76.67 & 1.83 & 1.93 & 1.88 \\
\hline 12. & CHFG-12 & 4.31 & 4.42 & 4.37 & 2.83 & 2.84 & 2.84 & 23.78 & 24.85 & 24.31 & 60.67 & 61.34 & 61.0 & 1.43 & 1.52 & \begin{tabular}{|l|l|}
1.47 \\
\end{tabular} \\
\hline 13. & CHFG-13 & 2.72 & 2.76 & 2.74 & 2.42 & 2.44 & 2.43 & 17.45 & 18.72 & 18.08 & 85.34 & 86.00 & 85.66 & 1.48 & 1.60 & 1.54 \\
\hline 14. & CHFG-14 & 2.89 & 2.93 & 2.91 & 2.41 & 2.42 & 2.41 & 18.38 & 19.44 & 18.91 & 66.67 & 67.34 & 67.0 & 1.12 & \begin{tabular}{|l|}
1.20 \\
\end{tabular} & 1.26 \\
\hline \multirow[t]{4}{*}{15.} & CHFG-15 & 2.64 & 2.69 & 2.67 & 2.95 & 2.99 & 2.97 & 21.36 & 21.85 & 21.60 & 64.34 & 65.00 & 64.66 & 1.37 & 1.41 & 1.39 \\
\hline & Mean & 3.61 & \begin{tabular}{|l|}
3.68 \\
\end{tabular} & 3.64 & 2.64 & 2.67 & 2.65 & 22.40 & 23.33 & 22.87 & \begin{tabular}{|l|}
73.17 \\
\end{tabular} & 74.05 & 73.61 & 1.63 & 1.71 & 1.62 \\
\hline & $\mathrm{CV} \%$ & 7.96 & 8.66 & 7.51 & 5.96 & 6.06 & 5.43 & 6.68 & 5.59 & 5.65 & 3.96 & 2.65 & 3.05 & 9.09 & 6.80 & 7.30 \\
\hline & SEm \pm & 0.16 & 0.18 & 0.11 & 0.09 & 0.09 & 0.05 & 0.86 & 0.75 & 0.52 & 1.67 & 1.13 & 0.91 & 0.08 & 0.06 & 0.04 \\
\hline \multicolumn{2}{|c|}{ CD or LSD (5\%) } & 0.48 & 0.53 & 0.31 & 0.26 & 0.27 & 0.16 & 2.51 & 2.17 & 1.49 & 4.86 & 3.28 & 2.59 & 0.24 & 0.19 & 0.14 \\
\hline
\end{tabular}

Table.3 Biochemical components of different wild brinjal (Solanum gilo) genotypes

\begin{tabular}{|c|c|c|c|c|c|c|c|c|}
\hline S.N. & Genotype & $\begin{array}{c}\text { Total carbohydrate } \\
(\mathrm{mg} / 100 \mathrm{~g})\end{array}$ & $\begin{array}{c}\text { Total phenol } \\
(\mathrm{mg} / 100 \mathrm{~g})\end{array}$ & $\begin{array}{c}\text { Ascorbic acid } \\
(\mathrm{mg} / 100 \mathrm{~g})\end{array}$ & $\begin{array}{c}\text { Total alkaloid } \\
(\mathrm{mg} / \mathbf{1 0 0 g})\end{array}$ & $\begin{array}{c}\text { Steroid content } \\
(\mu \mathrm{g} / \mathbf{1 0 0 g})\end{array}$ & $\begin{array}{c}\text { Flavonoid content } \\
(\mathrm{mg} / 100 \mathrm{~g})\end{array}$ & Total protein $(\mathrm{mg} / \mathbf{1 0 0 g})$ \\
\hline 1. & CHFG-1 & 337.74 & 19.58 & 12.74 & 3.90 & 179.70 & 10.80 & 155.78 \\
\hline 2. & CHFG-2 & 315.51 & 18.36 & 14.76 & 3.76 & 176.89 & 12.49 & 154.29 \\
\hline 3. & CHFG-3 & 344.68 & 22.41 & 11.54 & 3.15 & 195.48 & 10.61 & 143.75 \\
\hline 4. & CHFG-4 & 375.78 & 27.39 & 16.73 & 4.68 & 190.49 & 13.58 & 160.34 \\
\hline 5. & CHFG-5 & 356.62 & 15.27 & 10.61 & 3.78 & 174.50 & 11.81 & 150.14 \\
\hline 6. & CHFG-6 & 338.70 & 16.74 & 9.87 & 2.68 & 184.84 & 9.81 & 128.76 \\
\hline 7. & CHFG-7 & 331.62 & 20.67 & 12.78 & 2.81 & 180.45 & 10.56 & 149.85 \\
\hline 8. & CHFG-8 & 350.68 & 17.63 & 10.72 & 3.60 & 174.26 & 11.64 & 151.19 \\
\hline 9. & CHFG-9 & 361.64 & 25.60 & 15.81 & 4.43 & 187.80 & 12.86 & 152.61 \\
\hline 10. & CHFG-10 & 341.71 & 23.36 & 12.79 & 3.59 & 192.68 & 10.85 & 139.50 \\
\hline 11. & CHFG-11 & 319.69 & 18.44 & 13.87 & 3.81 & 178.47 & 11.91 & 154.83 \\
\hline 12. & CHFG-12 & 327.72 & 24.29 & 15.78 & 4.42 & 178.28 & 13.24 & 148.70 \\
\hline 13. & CHFG-13 & 330.64 & 26.32 & 9.76 & 3.98 & 190.84 & 12.69 & 132.65 \\
\hline 14. & CHFG-14 & 348.52 & 21.46 & 13.37 & 2.94 & 183.72 & 10.70 & 146.90 \\
\hline 15 & CHFG-15 & 354.46 & 20.65 & 14.50 & 3.82 & 182.73 & 11.17 & 136.70 \\
\hline \multicolumn{2}{|c|}{ Mean } & 342.38 & 21.21 & 13.04 & 3.69 & 183.41 & 11.65 & 147.06 \\
\hline \multicolumn{2}{|c|}{ CV \% } & 0.13 & 1.23 & 1.83 & 3.35 & 0.17 & 2.14 & 0.18 \\
\hline \multicolumn{2}{|c|}{ SEm \pm} & 0.26 & 0.15 & 0.13 & 0.07 & 0.18 & 0.14 & 0.15 \\
\hline \multicolumn{2}{|c|}{ CD or LSD (5\%) } & 0.78 & 0.43 & 0.40 & 0.20 & 0.53 & 0.41 & 0.45 \\
\hline
\end{tabular}


Maximum fruit weight was observed in CHFG-4 (27.86) while CHFG-6 (16.70) had minimum weight. Maximum number of fruits per plant was observed in CHFG-5 (93.66) while it was minimum in CHFG-12 (61.00). Maximum fruit yield per plant was recorded in CHFG-5 (1.97) which was statistically at par with CHFG-4 (1.95), CHFG-1 (1.90), CHFG-11 (1.88), CHFG-8 (1.82) and CHFG2 (1.85). Similar results of variability in fruit characters and yield in brinjal were also obtained by Madhavi et al., (2015), Mili et al., (2014) and Prabakaran et al., (2013).

\section{Biochemical components}

The biochemical constituents varied in all the genotypes (Table 3). Wild brinjal (Solanum gilo) is very nutritive and useful vegetable because it is rich source of protein, minerals, crude fibre, phenolic content, antioxidant activity and important essential amino acids. In the present investigation, total carbohydrate content was lowest in CHFG-2 (315.51) followed by CHFG-11 (319.69) and found highest in CHFG-4 (375.78). Highest total phenol content was observed in CHFG-4 (27.39) while CHFG-5 (15.27) had lowest total phenol content. The genotypes with low total phenol content can be exploited for breeding quality fruits. CHFG-4 (16.73) had the highest ascorbic acid content followed by CHFG-9 (15.81) while minimum ascorbic acid content was recorded in CHFG-13 (9.76). CHFG-6 (2.68) had the lowest total alkaloid content which was statistically at par with CHFG-7 (2.81) while highest content was recorded in CHFG- 12 (4.68). Minimum steroid content was observed in CHFG-8 (174.26) while maximum content was observed in CHFG-3 (195.48). Maximum flavonoid content was observed in CHFG-12 (13.58) which was statistically at par with CHFG-4 (13.24) while minimum flavonoid content. Total protein content was found to be highest in CHFG-1 (160.34) followed by
CHFG-4 (155.78) while total protein content was found lowest in CHFG-13 (128.76). The present findings of variability in biochemical components are in agreement with Umesh et al., (2015), Eze and Kanu (2014), Tripathi et al., (2014), Amadi et al., (2013) and Chinedu et al., (2011). Solanum gilo fruits contained appreciable amounts of the compounds investigated; these compounds are bioactive and could be behind the nutritional and medicinal potentials of the fruits. On the basis of mean performance of the genotypes for all the traits studied, the genotypes CHFG-4 and CHFG-5 were found to be superior for the yield components and fruit quality traits. So, these genotypes might be used as parental source in any breeding programme.

\section{Acknowledgements}

The authors are thankful to Dean, College of Horticulture \& Forestry, Central Agricultural University, Pasighat, Arunachal Pradesh for providing all kinds of help during present investigation.

\section{References}

Amadi, B., Onuoha, N., Amadi, C., Ugbogu, A. and Duru, M. 2013. Elemental, amino acid and phytochemical constituents of fruits of three different species of eggplant. Int. J. Med. Aroma. Plants, 3(2): 200-203.

Bello, S.O., Muhammad, B.Y., Gammaniel, K.S., Abdu-Aguye, I., Ahmed, H., Njoku, C.H., Pindiga, U.H. and Salka, A.M. 2005. Preliminary evaluation of the toxicity and some pharmacological properties of the aqueous crude extract of Solanum melongena. Res. J. Agric. Biol. Sci., 1(1): 1-9.

Chinedu, S.N., Olasumbo, A.C., Eboji, O.K., Emiloju, O.C., Arinola, O.K. and Dania, D.I. 2011. Proximate and phytochemical analysis of Solanum 
aethiopicum L. and Solanum macrocarpon L. Fruits. Res.J. Chem. Sci., 1(3): 63-71.

Eze, S.O., and Kanu, C.Q. 2014. Phytochemical and nutritive composition analysis of Solanum aethiopicum. J. Pharm. Sci. Innov., 3(4): 358-362.

Gomez, K.A., and Gomez, A.A. 1983. Statistical procedure for agricultural research $2^{\text {nd }}$ edition, John Wiley and Sons, New York, pp. 375-427.

Hassan, I., Jatoi, S.A., Arif, M., Siddiqui, S.U. and Ahson, M. 2015. Genetic variability in eggplant for agromorphological traits. Sci. Technol. Dev., 34(1): 35-40.

Hedge, J.E., and Hofreiter, B.T.1962. In: Carbohydrate Chemistry, 17 (Eds. Whistler R.L. and Be Miller, J.N.), Academic Press, New York.

Jagota, S.K., and Dani, H.M. 1982. A new colorimetric technique for estimation of vitamin $\mathrm{C}$ using folin-phenol reagent. Ann. Biochem., 27(1):178-182.

Knapp, S., 2011. Solanum Section Geminata (Solanaceae). Flora Neotrop. Monograph, 84(1): 1-405.

Kumar, S. R., and Arumugam, T. 2013. Variability, heritability and genetic advance for fruit yield, quality and pest and disease incidence in eggplant. Veg. Sci., 40(1): 111-113.

Lowry, O.H., Rosebrough, N.J., Farr, A.L. and Randall, R.J. 1951. Protein measurement with the folin phenol reagent. J. Biol. Chem., 193: 265-275.

Madhavi, N., Mishra, A.C., Prasad, J.O. and Bahuguna, N. 2015. Studies on variability, heritability and genetic advance in brinjal (Solanum melongena L.). Plant Archives, 15(1): 277-281.

Malick, C.P., and Singh, M.B. 1980. In: Plant Enzymology and Histo Enzymology, Kalyani Publishers, New Delhi, p.286.

Mili, C., Bora, G.C., Das, B. and Paul, S.K.
2014. Studies on variability, heritability and genetic advance in Solanum melongena L. genotypes. Direct Res. J. Agric. Food Sci., 2(11): 192-194.

Odetola, A.A., Iranloye, Y.O. and Akinloye, O. 2004. Hypolipidaemic potentials of Solanum melongena and Solanum gilo on hypercholesterolemic rabbits. Pakistan J. Nutr., 3(3): 180-187.

Prabakaran, S., Balakrishnan, S., Kumar, S.R., Arumugam, T. and Premalakshmi, V. 2013. Performance and genetic variability in eggplant germplasm. $J$. Progressive. Agric., 4(2): 98-105.

Sanchez-Mata, M.C., Yokoyama, W.E., Hong, Y.J. and Prohens, J. 2010. $\alpha-$ solasonine and $\alpha$-solamargine contents of Gboma (Solanum macrocarpon L.) and Scarlet (Solanum aethiopicum L.) eggplants. J. Agric. Food Chem., 58(9): 5502-5508.

Singh, O., and Kumar, J. 2005. Variability, heritability and genetic advance in brinjal. Indian J. Hort., 62(3): 265-267.

Sunseri, F., Polignano, G.B., Alba, V., Lotti, C., Bisignano, V., Mennella, G., Alessandro, A.D., Bacchi, M., Riccardi, P., Fiore, M.C. and Ricciardi, L. 2010. Genetic diversity and characterization of African eggplant germplasm collection. African J. Plant Sci., 4: 231241.

Toppino, L., Vale, G. and Rotino, G. L. 2008. Inheritance of Fusarium wilt resistance introgressed from Solanum aethiopicum Gilo and aculeatum groups into cultivated eggplant (Solanum melongena) and development of associated PCR-based markers. Mol. Breed., 22: 237-250.

Tripathi, M., Singh, P., Pandey, P., Pandey, V.R. and Singh, H. 2014. Antioxidant activities and biochemical changes in different cultivars of brinjal (Solanum melongena L.). American J. Plant Physiol., 9(1): 24-31. 
Umesh, K.K., Vijay, K.B., Nikunj, K.B., Neha, P.B. and Baljibhai, A.G. 2015. Antioxidant and nutritional components of eggplant (Solanum melongena L.) fruit grown in Saurastra Region. Int. J. Curr. Microbiol. Appl. Sci., 4(2): 806813.

Vijay, D.T. and Rajendra, S.B. 2014. Estimation of total phenol, tannin, alkaloid and flavonoid in Hibiscus tiliaceus L. Wood extracts. Research and Review: J. Pharmacog. Phytochem, 2(4): 41-47.

Yadav, V., Mehta, N., Rangare, S.B. and Sahu, E. 2014. Variability and heritability estimates in the germplasm collection of eggplant (Solanum melongena L.). Trends Biosci, 7(21): 3482-3484.

\section{How to cite this article:}

Lalhming Sanga, A.K. Pandey, S.D. Warade, B.N. Hazarika and Siddhartha Singh. 2017. Assessment of Wild Brinjal (Solanum gilo) Genotypes of North-Eastern Region. Int.J.Curr.Microbiol.App.Sci. 6(10): 1451-1458. doi: https://doi.org/10.20546/ijcmas.2017.610.171 